\title{
Infiltrating orbital granular cell tumour: a case report and literature review
}

\author{
PETER J DOLMAN,' JACK ROOTMAN,${ }^{2}$ AND CLARISSE L DOLMAN ${ }^{1}$ \\ From the Departments of 'Pathology, Vancouver General Hospital, and ${ }^{2}$ Ophthalmology, University of British \\ Columbia, Vancouver, British Columbia, Canada
}

\begin{abstract}
SUMMARY A surgical biopsy of an infiltrative retrobulbar mass in a 44-year-old man was diagnosed as granular cell tumour. Electron microscopy and immunoperoxidase stains were used to confirm the diagnosis and to study the histogenesis of this rare soft tissue neoplasm. S-100 stain was positive, while neuron-specific enolase and myoglobin stains were negative, suggesting a nonspecific neural origin for the cells. The capability of this tumour to invade surrounding tissues has seldom been described in the orbit and is demonstrated by this case.
\end{abstract}

Granular cell tumour is an unusual neoplasm with uncertain histogenesis that rarely occurs in the orbit. It is regarded as a benign lesion, though it may locally invade surrounding tissues. The following case exemplifies such infiltrative behaviour within the orbit.

\section{Case report}

CLINICAL FINDINGS

A male native Indian boiler maker was first seen in Alberta in December 1984 at age 44 complaining of progressive horizontal diplopia of one month's duration. His corrected vision was $20 / 60$ right and 20/20 left and he had restricted right abduction and supraduction. A CT scan showed an irregular enhancing mass posterior to the right globe and inferotemporal to the optic nerve. A biopsy of this lesion was reported as atrophic skeletal muscle with marked fibrosis and low grade chronic inflammation. With a presumed diagnosis of fibrosing pseudotumour, he was started on a course of oral prednisone.

Over the next 10 months his vision and diplopia subjectively worsened and he was referred to Vancouver in October 1985 for further evaluation. He had no other ocular or systemic complaints and was on no medications. Past medical history included three years of diet controlled diabetes mellitus and pulmonary tuberculosis in 1961 . The family history contributed nothing relevant.

Correspondence to Jack Rootman, MD, Eye Care Centre, 2550 Willow Street, Vancouver, BC, Canada V5Z 3N9.
On physical examination his visual acuity remained at 20/60 OD and 20/20 OS, and visual fields were full to confrontation. The interpalpebral fissures were $9 \mathrm{~mm}$ right and $8 \mathrm{~mm}$ left. The right globe was elevated $2 \mathrm{~mm}$ and laterally displaced $1 \mathrm{~mm}$. Exophthalmometry measured $15 \mathrm{~mm}$ right and $12 \mathrm{~mm}$ left. Ocular movements were full on the left but on the right were restricted to $10^{\circ}$ in abduction and elevation with normal remaining ductions. Applanation tonometry was $14 \mathrm{~mm}$ bilaterally. Pupils were equally reactive to light and accommodation. Fundus examination showed choroidal folds inferolateral to the macula on the right side.

Routine blood analysis and chest $x$-ray were normal. A CT scan showed a uniformly enhancing homogeneous soft tissue mass, 13 by 13 by $15 \mathrm{~mm}$, in the right retrobulbar space with well defined posterolateral margins but irregular medial border (Fig. 1). It indented the globe posteriorly and displaced the optic nerve medially (Fig. 2). No calcification was seen. Ultrasound indicated slight thickening of the sclera adjacent to the mass.

Visually evoked potentials were delayed and of low voltage for the right eye, with a broad peak with multiple small components, suggesting optic neuropathy secondary to an infiltrative rather than a compressive process.

On 11 October 1985 the patient underwent lateral orbitotomy under general anaesthesia. A firm, rounded, tan-grey mass was noted posterior to the globe and spreading inferolaterally next to the lateral rectus muscle. The tumour was sclerotic, with little vascularity, and appeared to invade the sclera and 


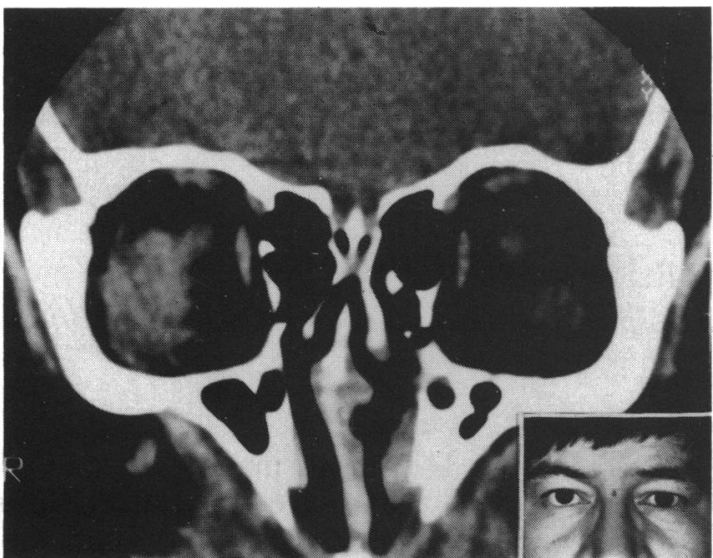

Fig. 1 Coronal computed tomographic scan shows an irregular mass in the right inferolateral orbit in contact with the optic nerve. Inset shows patient with right proptosis and inferior scleral show.

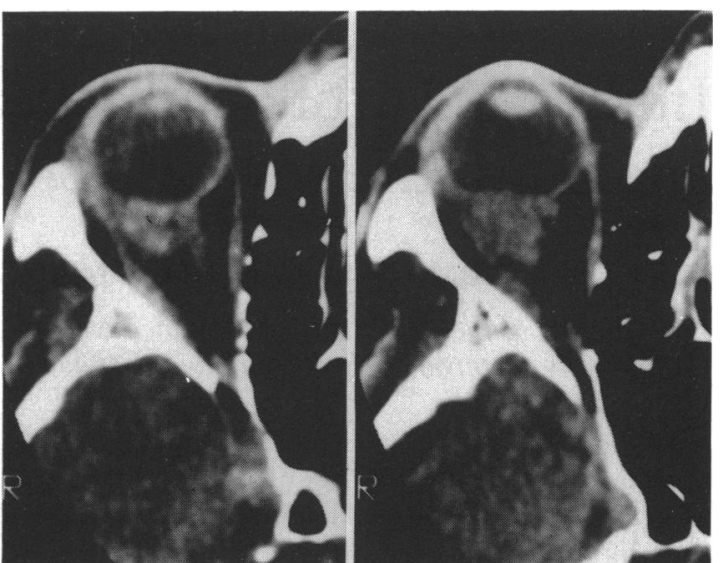

Fig. 2 Axial computed tomographic scan shows right retrobulbar irregular mass displacing the optic nerve medially and indenting the globe posteriorly. Left: superior cut. Right: inferior cut.

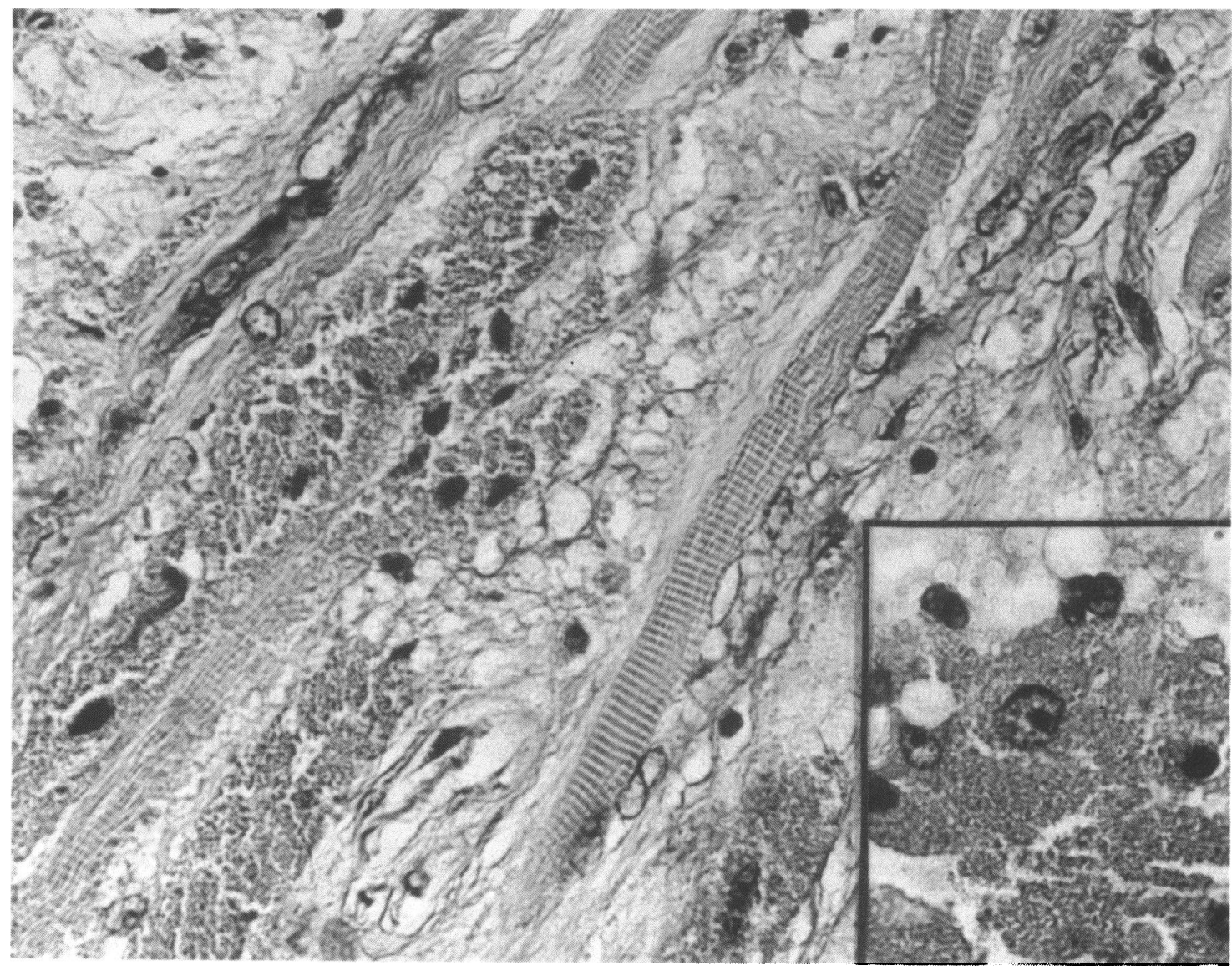

Fig. 3 Tumour from right orbit shows plump granular cells invading surrounding striated muscle cells. Inset shows individual cells with prominent nucleoli and cytoplasmic granules. (Haematoxylin and eosin). 


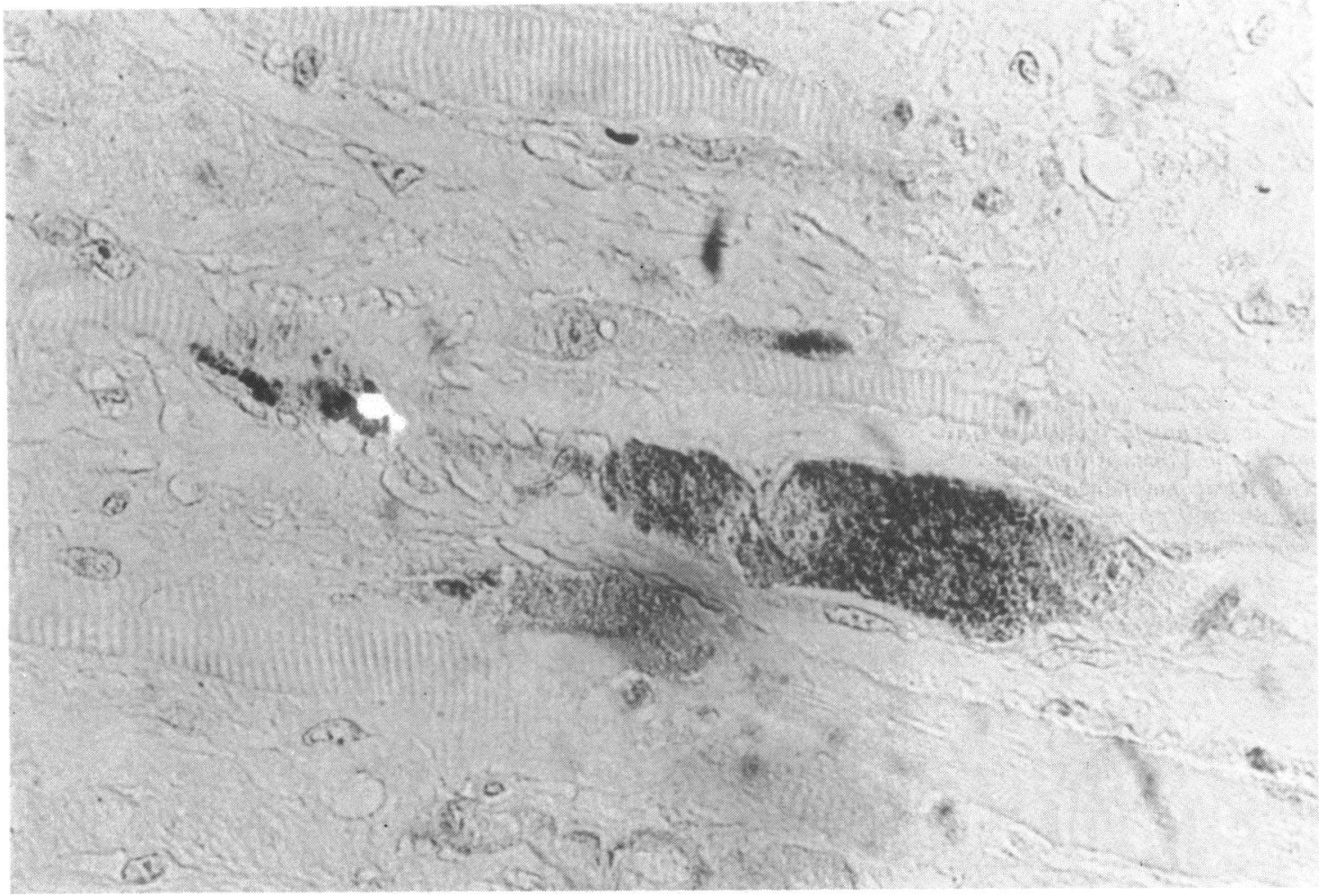

Fig. 4 S-100 positive granular tumour cell lies among non-staining skeletal muscle cells.

around the optic nerve, making complete excision impossible. Multiple sections aggregating to $1 \mathrm{~cm}$ were removed for pathological study and either fresh frozen or fixed in formalin, glutaraldehyde, and $\mathrm{B}_{5}$.

\section{PATHOLOGICAL FINDINGS}

The tumour consisted of nests and ribbons of large round and polygonal cells. These contained paracentral, vesicular nuclei with prominent nucleoli and abundant cytoplasm replete with striking coarse eosinophilic granules (Fig. 3). The cells lay close to peripheral nerve bundles and normal striated muscles and were surrounded by dense fibrous scar tissue with a few scattered lymphocytes and plasmacytes. Neither mitotic figures nor necrosis were present.

The cytoplasmic granules were moderately periodic acid Schiff positive, diastase resistant, and stained Indian red with Masson's trichrome. They were negative for luxol fast blue. Bodian stain showed individual axons streaming alongside many of the granular cells. The tumour cells were strongly positive for S-100 protein (as were the Schwann cells in nerve bundles but not skeletal muscle fibres) and negative for myoglobin and neuron-specific enolase (Fig. 4).

Characteristic ultrastructural features were noted on electron microscopy. ${ }^{1}$ The granular cells lay mostly in small clusters and had short interdigitating processes with rare primitive intercellular junctions (Fig. 5). A basement lamina often surrounded clumps but did not extend between adjacent individual cells. The nuclei were irregularly oval or round, with dispersed chromatin and medium sized nucleoli. The cytoplasm bulged with numerous pleomorphic lysosomal-like round bodies lined by single and occasionally double limiting membranes and filled with granular dense material, numerous small vesicles, and concentric laminated bodies (Figs. $6,7)$. The cytoplasm also contained free ribosomes, sheets of mitochondria, irregularly arranged intermediate filaments (Fig. 8), and one membrane bound space containing a group of collagen fibres. A second more sparse population of single small angulate cells contained oblong bodies composed of fibrillary material surrounded by a unit membrane (Fig. 9). Small nerves and striated muscle fibres were also present but were distinctly separate from the tumour cells. 
Fig. 5 Clusters of granular tumour cells are surrounded by a basal lamina (open arrow) and connect with interdigitating processes with primitive junctions (solid arrow).

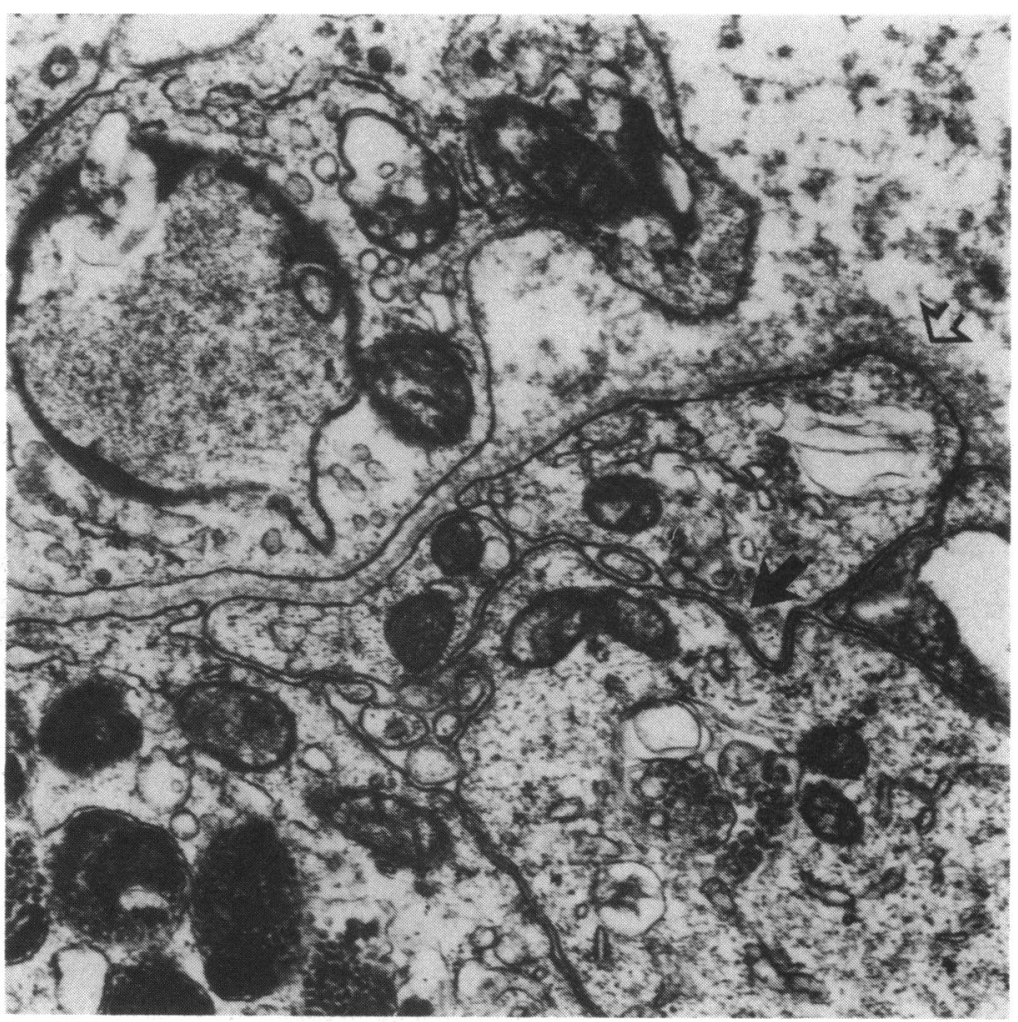

Abrikossoff in $1926 .{ }^{3}$ Almost any organ or body tissue may be affected, though the most common sites are tongue, chest wall, and arm. Other cases have occurred in larynx, digestive tract, breast, female anogenital region, and pituitary stalk. ${ }^{4}$

Over 500 cases of granular cell tumours have been reported $^{2}$ since the first case in the tongue by

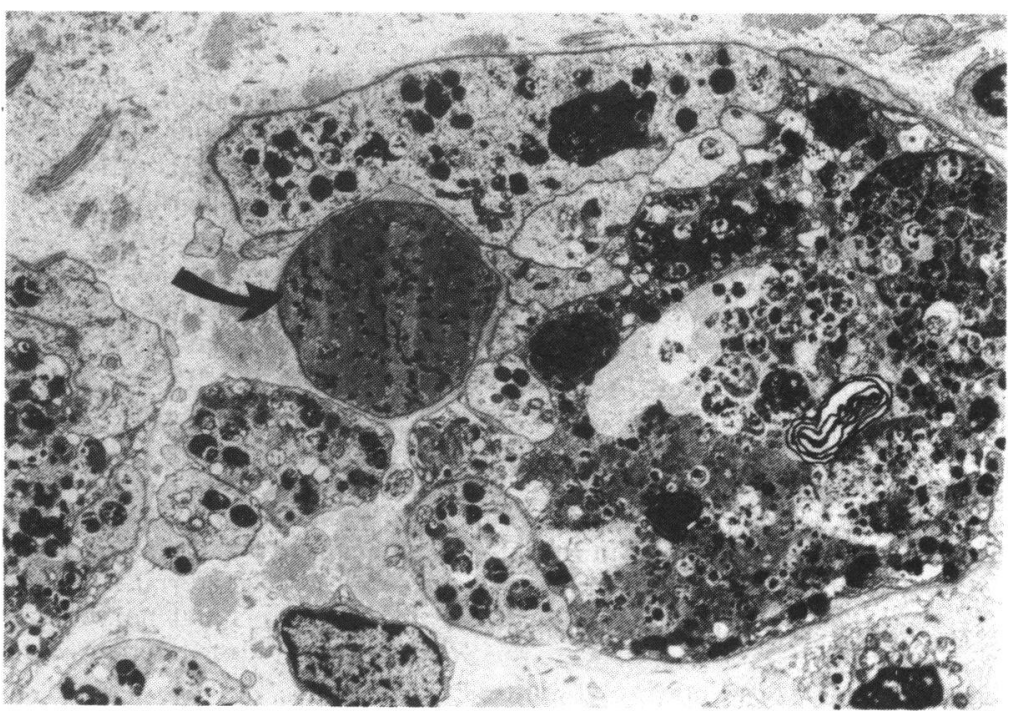

Fig. 6 Several granularcells containing pleomorphic dense granules; complex vesicles and a myelin figure surround a muscle fibre (arrow). 


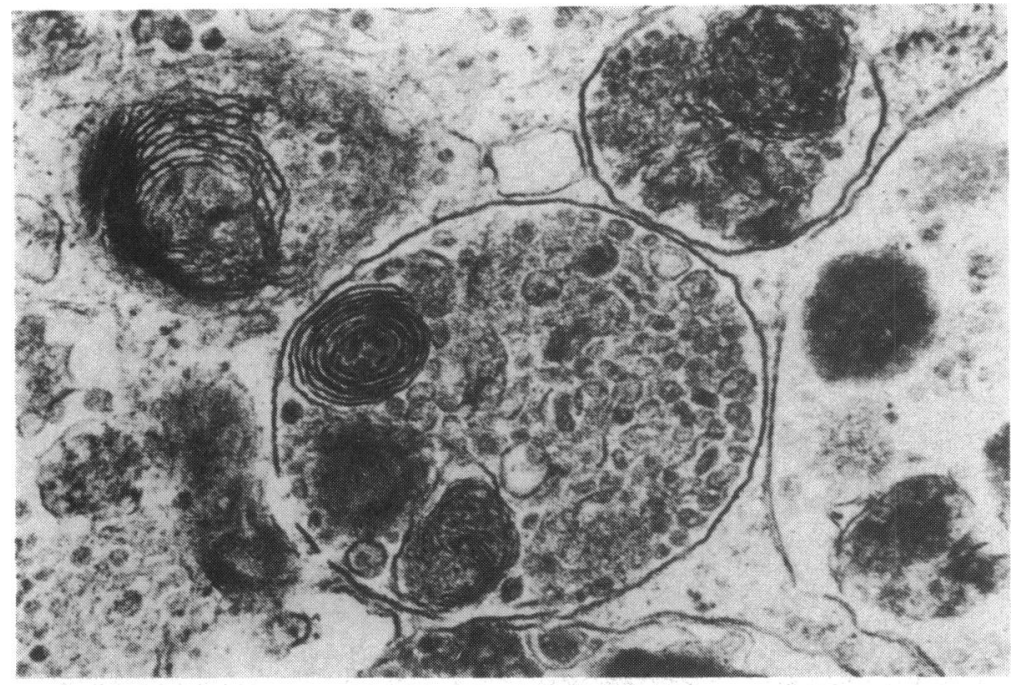

Fig. 7 Complex cytoplasmic vesicles contain lamellar figures and smaller vesicles and granules.

The tumour may occur at any age, though is most common between 40 and 70 years. Women are more frequently affected than men. It typically presents as a solitary, non-tender, firm nodule less than $6 \mathrm{~cm}$ in diameter present for less than a year. It may be well circumscribed or infiltrate into the surrounding tissue. Between 10 and $15 \%$ of granular cell tumours are multicentric and 1 to $3 \%$ are malignant. ${ }^{5}$

Orbital involvement has previously been described in only 15 patients. ${ }^{6-19}$ Other cases in or near the eye have arisen in uvea, conjunctiva, caruncle, lacrimal sac, eyebrows, and eyelids. ${ }^{18}$ Retrobulbar tumours adjacent to the optic nerve have been reported four times previously ${ }^{1121518}$ and in one case caused optic neuropathy ${ }^{12}$ similar to our case. Unlike their counterparts elsewhere in the body, granular cell tumours in the orbit have characteristically been described as discrete and well encapsulated. Only one case of orbital malignancy has been recorded. ${ }^{6}$

\section{HISTOGENESIS}

The histogenesis of granular cell tumour remains controversial. An origin from striated muscle was first proposed by Abrikossoff ${ }^{3}$ and appeared to be supported by tissue culture studies of Murray. ${ }^{20}$ However, development of tumour in areas lacking muscle and the lack of typical muscle ultrastructural components have largely discounted this theory.

Azzopardi suggested that these tumours were of histiocytic origin because of the abundance of

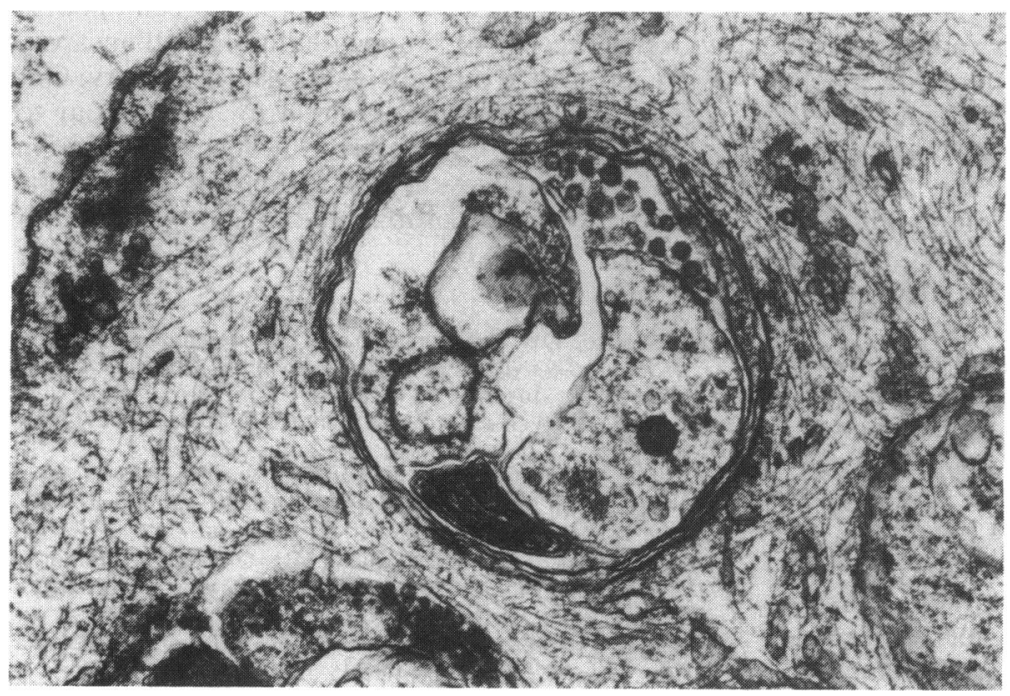

Fig. 8 Several complex vesicles nest in a bed of intracytoplasmic filaments. 
Fig. 9 Filamentous angulate body lies adjacent to granular cell tumour nucleus.

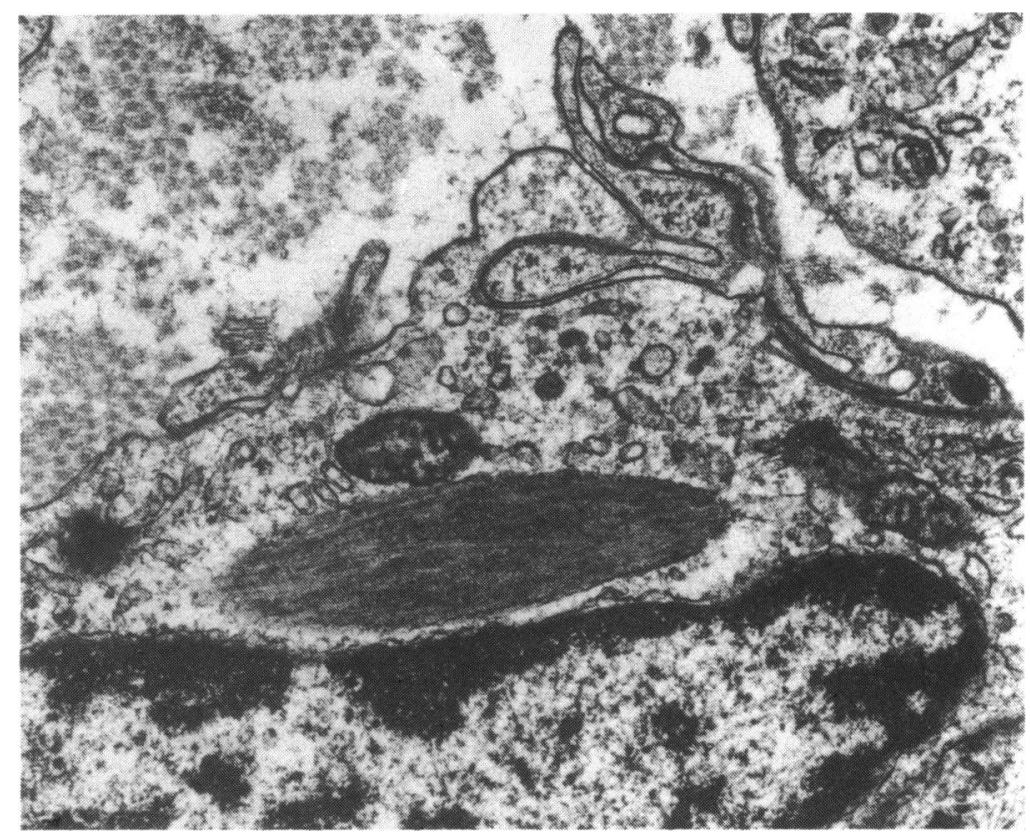

lysosomes and their enzymes. ${ }^{21}$ This is now considered unlikely, because the tumour cells lack specific histiocytic markers such as lysozyme and $\alpha_{1}$ antitrypsin..$^{22}$

In 1935 Feyrter suggested a neural origin, and this is currently receiving increasing support. ${ }^{23}$ Candidates for the cell of origin include perineural fibroblasts ${ }^{24}$ Schwann cells, ${ }^{25}$ and primitive precursor mesenchymal cells with the potential to differentiate into Schwann or granular cells. ${ }^{22}$ Proponents of Schwann cells note the tumour's frequent association with peripheral nerves and electron microscopy showing a basal lamina around cells and cytoplasmic inclusions reminiscent of degenerated myelin. Others report positive histochemical staining of the granules for cerebrosides and other myelin degeneration products. However, we and others found only cell groups surrounded by a basal lamina rather than individual cells as in Schwann cell tumours. ${ }^{22}$ Further, our case stained negative for lipid and myelin, confirming similar results of Morgan. ${ }^{13}$

Special immunochemical stains also support a neural origin. S-100 protein is an acidic protein present in glial cells of the central nervous system and peripherally in Schwann cells, spinal ganglion satellite cells, melanocytes, and other cells of neural crest origin. Granular cell tumours have been consistently S-100 positive in several series ${ }^{2627}$ but are negative for myoglobin, a muscle marker ${ }^{28}$ Our case showed a similar pattern. Neuron-specific enolase, present in nerve cells and absent in Schwann cells, was identified in eight granular cell tumours tested by Rode et al.,${ }^{29}$ but was negative in ours.

Thus the evidence, corroborated by our findings, suggests neural differentiation for granular cell tumour, but the exact cell of origin remains uncertain.

\section{TREATMENT}

The treatment of granular cell tumour is wide surgical excision. The reported local recurrence rate is less than $7 \% .^{2}$ Radiotherapy has not proved helpful. ${ }^{5}$

In previous cases the orbital granular cell tumour, with two exceptions, ${ }^{68}$ appeared to be well encapsulated and shelled out relatively easily at surgery. Our case demonstrates the potential for the tumour to infiltrate tissues in the orbit as it does elsewhere in the body. Progression and extension make total exenteration a grim probability.

\section{References}

1 Henderson DW, Papadimitriou JM. Ultrastructural appearances of tumours-a diagnostic atlas. Edinburgh: Churchill Livingstone, 1982: 210-2.

2 Enzinger F, Weiss S. Soft tissue tumors. St Louis: Mosby, 1983: 745-56.

3 Abrikossoff A. Über Myome ausgehend von der quergestreiften willkürlichen Muskulatur. Virchows Arch (Pathol Anat) 1926; 260: 215-33.

4 Lack EE, Worsham GF, Callihan MD. Granular cell tumor: a clinicopathologic study of 110 patients. J Surg Oncol 1980; 13: 301-6.

5 Kubacz GJ. Malignant granular cell myoblastoma: report of a case. Aust NZJ Surg 1971; 40: 291-5. 
6 Dunnington JH. Granular cell myoblastoma of the orbit. Arch Ophthalmol 1948; 40: 14-22.

7 Sakamaki Y. A case of intraorbital myoblastoma. Jpn J Clin Ophthalmol 1963; 17: 883-4.

8 Timm G, Timmel H. Zum Myoblastenmyom am Auge. Klin Monatsbl Augenheilkd 1966; 148: 665-71.

9 Obayashi K, Yamada Y, Kozaki M. Granular cell myoblastoma in the orbit. Folia Ophthalmol Jpn 1969; 20: 566-74.

10 Morgan LR, Fryer MP. Granular cell myoblastoma of the eye: case report. Plast Reconstr Surg 1969; 43: 315-7.

11 Chaves E, Oliveira AM, Arnaud AC. Retrobulbar granular cell myoblastoma. BrJ Ophthalmol 1972; 56: 854-6.

12 Gonzales-Almarez G, de Buen S, Tsutsumi V. Granular cell tumor (myoblastoma) of the orbit. Am J Ophthalmol 1975; 79: 606-12.

13 Morgan G. Granular cell myoblastoma of the orbit. Arch Ophthalmol 1976; 94: 2135-42.

14 Drummond JW, Hall DL, Steen WH, Maxey SA. Granular cell tumor (myoblastoma) of the orbit. Arch Ophthalmol 1979; 97: 1492-4.

15 Goldstein BG, Font RL, Alper MG. Granular cell tumor of the orbit: a case report including electron microscopic observations. Ann Ophthalmol 1982; 14: 231-8.

16 Singleton EM, Nettleship M. Granular cell tumor of the orbit: a case report. Ann Ophthalmol 1983; 15: 881-3.

17 Karcioglu ZA. Granular cell tumor of the orbit. Case report and review of the literature. Ophthalmic Surg 1983; 14: 125-9.

18 Moriarty P, Garner A, Wright JE. Case report of granular cell myoblastoma arising within the medial rectus muscle. $\mathrm{Br} \mathrm{J}$ Ophthalmol 1983; 67: 17-22.

19 Shimoyama I. Granular cell myoblastoma in the orbit. Neurol Med Chir (Tokyo) 1984; 24: 355-8.
20 Murray MR. Cultural characteristics of three granular cell myoblastomas. Cancer 1951; 4: 857-65.

21 Azzopardi JG. Histogenesis of granular cell myoblastoma. J Pathol Bacteriol 1956; 71: 85-94.

22 Miettinen M, Lehtonen E, Lehtola H, Ekblom P, Lehto V, Virtanen I. Histogenesis of granular cell tumor-an immunohistochemical and ultrastructural study. J Pathol 1984; 142: 221-9.

23 Feyrter F. Über eine eigenartige Geschwulstform des Nervengewebes im menschlichen Verdauungsschlauch. Virchows Arch (Pathol Anat) 1935; 295: 480-501.

24 Constanzi G, Bosincu L, Denti S, Pittaluga S, Sanna E. Evidence for collagen fibrils inside the cells of granular cell myoblastomas. Pathol Res Pract 1980; 170: 61-9.

25 Fisher ER, Wechsler H. Granular cell myoblastoma-a misnomer. Electron microscopic and histochemical evidence concerning its Schwann cell derivation and nature (granular cell Schwannoma). Cancer 1962; 15: 936-54.

26 Stefansson K, Wollmann RL. S-100 protein in granular cell tumors (granular cell myoblastomas). Cancer 1982; 49: 1834-8.

27 Armin A, Connelly E, Rawden G. An immunoperoxidase investigation of S-100 protein in granular cell myoblastomas: evidence for Schwann cell derivation. Am J Clin Pathol 1983; 79: 37-44.

28 Ingram DL, Mossler J, Snowhite J, Leight GS, McCarty KS. Granular cell tumors of the breast-steroid receptor analysis and localization of carcinoembryonic antigen, myoglobin and $\mathrm{S} 100$ protein. Arch Pathol Lab Med 1984; 108: 897-901.

29 Rode J, Dhillon AP, Papadaki L. Immunohistochemical staining of granular cell tumour for neurone-specific enolase: evidence in support of a neural origin. Diagn Histopathol 1982; 5: 205-11.

Accepted for publication 17 April 1986. 